\title{
Modelo matemático pra uma coisa que não é matemática: narrativas de médicos/as infectologistas sobre carga viral indetectável e intransmissibilidade do HIV
}

\author{
| ${ }^{1}$ Luís Augusto Vasconcelos da Silva, ${ }^{2}$ Filipe Mateus Duarte, ${ }^{3}$ Mônica Lima |
}

Resumo: Este artigo parte de uma discussão internacional sobre a intransmissibilidade do vírus HIV, quando a pessoa soropositiva está em tratamento e com carga viral indetectável. Trata-se de um dos resultados da pesquisa qualitativa sobre sociabilidades de jovens vivendo com HIV, com ênfase nos novos discursos/práticas biomédicos e seu impacto nas relaçóes afetivo-sexuais desses/as jovens. Durante os meses de março a novembro de 2017, houve a interação com pessoas vivendo com HIV/Aids (PVHA), com idade entre 18 e 30 anos, e médicos/ as infectologistas de um Serviço de Assistência Especializada em Salvador-BA. Para além das mudanças significativas em relação ao HIV, decorrentes dos avanços atuais das biotecnologias, colocamos em pauta algumas controvérsias em torno da intransmissibilidade do vírus do ponto de vista de quatro médicos/as infectologistas. Realizamos entrevistas abertas e a leitura exploratória das narrativas, identificando temas, questóes e atores que se deslocavam nos relatos em torno da condição de indetectável. Discutimos que a carga viral indetectável aparece como um assunto delicado/controverso nos consultórios médicos, atualizando a posição de PVHA como potencialmente perigosas, podendo reincidir em práticas sexuais desprotegidas ou "relaxar" no cuidado consigo e com o outro. São narrativas que suscitam questóes éticas fundamentais na relação de cuidado, tais como o direito à informação na perspectiva da saúde como um direito humano.

> Palavras-chave: HIVIAids; carga viral indetectável; biotecnologias; risco; práticas de cuidado.

\author{
${ }^{1}$ Instituto de Humanidades, Artes \\ e Ciências, Universidade Federal \\ da Bahia. Salvador-BA, Brasil \\ (gugavascon@gmail.com). \\ ORCID: 0000-0003-0742-9902 \\ 2 Psicologia, Universidade Federal \\ da Bahia. Salvador-BA, Brasil \\ (filipemateusduarte@gmail.com). \\ ORCID: 0000-0001-5508-8773 \\ ${ }^{3}$ Psicologia, Universidade Federal \\ da Bahia. Salvador-BA, Brasil \\ (molije@hotmail.com). \\ ORCID: 0000-0002-6666-8463
}

Recebido em: 29/08/2019 Aprovado em: 12/09/2019 Revisado em: 20/02/2020 


\section{Introdução}

Este artigo é um dos resultados de uma pesquisa qualitativa sobre sociabilidades de jovens vivendo com HIV, com ênfase nos novos discursos/práticas biomédicos e seu impacto nas relaçôes afetivo-sexuais desses/as jovens. ${ }^{1}$ Para além das novas possibilidades e mudanças significativas em relaçáo ao viver com HIV, decorrentes dos avanços atuais das biotecnologias, neste artigo pretendemos colocar em pauta alguns dilemas e controvérsias em torno da não transmissibilidade do vírus, do ponto de vista de quatro médicos infectologistas. Conforme será discutido, apesar do reconhecimento e da importância destes avanços, ainda persiste um discurso (moral) sobre o risco de transmissão/circulação do HIV, ao mesmo tempo em que outras atuaçôes passam a ocorrer neste cenário.

No bojo do recrudescimento da epidemia de HIV/Aids entre gays e outros Homens que fazem sexo com homens (HSH) (BRASIL, 2017; GUIMARÁES et al., 2018), observa-se o otimismo da comunidade científica, principalmente com evidências recentes, no campo biomédico, de que uma pessoa vivendo com HIV, quando em tratamento com antirretrovirais e atingindo carga viral indetectável, não transmite o vírus durante suas relaçôes sexuais (COHEN et al., 2016; GRULICH et al., 2015; RODGER et al., 2016, 2019; THE LANCET HIV, 2017). Por outro lado, diferentes pesquisas e análises também têm apontado que o estigma em torno do HIV continua a produzir barreiras socioafetivas na vida de pessoas com diagnóstico positivo (FLOWERS, 2010), mesmo com a disponibilização de uma gama variável de novas drogas/terapias e, consequentemente, de aparente saída do "excepcionalismo do HIV/ Aids" para sua "normalização" como uma doença crônica (DE COCK; JOHNSON, 1998, p. 291). Na "nova" Aids, conforme destaca Simōes (2018), as pessoas vivendo com HIV, principalmente aquelas que contraíram o HIV por via sexual, podem ainda serem vistas como "ameaça", experimentando sentimentos de culpa e vergonha, podendo ser responsabilizadas pelo "dano" que causaram a si e que podem causar a outros. Mais precisamente em relação a HSH/gays, os estigmas parecem se acumular ou se intensificar, quando continuam associados à promiscuidade, a uma sexualidade tida como "irresponsável", decorrente de "uma falta de controle de si" (SIMÓES, 2018, p. 335). Não é à toa, por exemplo, como destacam Jeffries et al. (2015), que ainda há relatos de que a infecção por HIV entre gays e outros HSH é uma questáo de "merecimento", um tipo de punição devido a um comportamento visto como imoral. 
Portanto, apesar de mudanças e descontinuidades relevantes no cenário do HIV/ Aids, há também problemas e conflitos que continuam a existir (SILVA; DUARTE; ALVES, 2017; SQUIRE, 2010), como também “incertezas" (DAVIS; FRANKIS; FLOWERS, 2006; ROSENGARTEN et al., 2004; SQUIRE, 2010) geradas pelas novas tecnologias médicas de tratamento e prevenção. Mais especificamente no que concerne à carga viral indetectável, do ponto de vista dos/as pacientes, há o surgimento de novos dilemas quando, por exemplo, alguém com carga viral indetectável se sente confuso, sem saber se pode confiar nos médicos, mediante a informação de que agora é mais fácil [tem mais chance] "passar" hepatite B do que transmitir o vírus HIV (DAVIS, 2007; 2010). Nessa direção, podemos também destacar novas versôes de "gerenciamento do risco", no sentido de que ao sujeito cabe fazer escolhas ou tomar decisóes com informaçōes técnicas disponíveis, reabrindo ou atualizando conflitos morais referentes ao período do HIV/Aids antes do advento de tratamentos mais efetivos (DAVIS, 2007).

É útil lembrar que o conceito moderno de risco está ligado à ideia de controle ou colonização do futuro (GIDDENS, 1997); em outras palavras, ao poder de decisão sobre "qual o futuro desejável" (CASTIEL, 2003, p. 83). Entretanto, se o mundo contemporâneo apresenta-se de forma mais aberta e contingente devido ao acúmulo de conhecimentos e sua consequente reflexividade sobre a vida cotidiana, por outro lado, emergem novas surpresas e "novos tipos de incalculabilidade" sobre o futuro (GIDDENS, 1997, p. 76). Nesse cenário, um novo sentimento de incerteza e indeterminação do mundo, em que "nada pode ser conhecido com segurança" (BAUMAN, 1998, p. 36) parece justificar ou dar novos contornos à existência dos riscos na vida cotidiana.

A partir de uma tendência crescente de globalização e desterritorialização dos efeitos dos riscos - da sociedade industrial para a sociedade de risco (BECK, 1992) ocorrem transformaçóes significativas sobre a crença na possibilidade de controle do futuro, bem como sobre o próprio gerenciamento dos riscos no espaço privado, que, como sustenta Spink (2001, p. 1.287), ao se desprender dos mecanismos tradicionais de vigilância (das instituiçốes disciplinares), "passa a depender do gerenciamento de informaçôes que são de todos e não são de ninguém”. Certamente, estamos diante de novas facetas ou particularidades da biopolítica descrita por Foucault (2001), ao destacar uma mudança importante nos mecanismos de poder a partir do séc. XVII, um deslocamento do direito de morte para um poder que se exerce positivamente sobre 
a vida. No cenário atual, mediado pelas biotecnologias, observa-se um deslocamento do Estado como regulador da saúde de indivíduos e populações para a autogestão da saúde (ORTEGA; ZORZANELLI, 2010). No caso da Aids, como uma doença crônica, tratável e manejável, na nova "era" de possibilidade de tratamento (DAVIS; SQUIRE, 2010; SQUIRE, 2010), há uma tendência "a deixar para a pessoa solitária a responsabilidade pela gestão de riscos” (SIMÓES, 2018, p. 335).

Por outro lado, para além de pensar em "escolhas" (de medicamentos/terapias ou condutas), gostaríamos de trazer outras linguagens/metáforas para falar sobre o “cuidado" em HIV, e mais precisamente sobre a carga viral indetectável. Conforme descreve Annemarie Mol (2008, p. 21), para além da disponibilidade de produtos (e escolhas), o cuidado é um "processo", sem fronteiras claras, ou seja, "não é uma transação em que alguma coisa é trocada (um produto contra um preço), mas uma interação em que as açóes vão para frente e para trás (em um processo contínuo)". Desse ponto de vista, considerando a própria imprevisibilidade dos corpos (e do mundo), o cuidado não pode ser pensado como um "produto bem delineado", mas como "um processo semiaberto", ou seja, em que há tentativas, ajustes e novas tentativas. Longe de ser uma atividade individual, o cuidado é um processo coletivo, cujas açôes encontram-se distribuídas entre diferentes atores (MOL, 2008), entre estes/estas, profissionais de saúde, pacientes, procedimentos/exames, médicos, células (CD4), vírus (carga viral), e outras pessoas (con)vivendo com HIV/Aids, com suas próprias histórias, experiências e dificuldades. Longe da ideia de "passividade" a que o termo paciente pode remeter, os/as pacientes são também ativos/as e fazem muitas coisas - atos contínuos e persistentes para permanecerem vivos/as.

Mol (1999) dá destaque também à performatividade para falar da realidade como múltipla. Nesse sentido, para além de um "objeto singular", ainda que possa ser pensado como "plural", considerando a possibilidade de muitas "perspectivas" ou visôes sobre o mesmo objeto (singular), a autora chama atenção para as diferentes versôes da realidade, ou seja: "versôes que os instrumentos ajudam a fazer/performar (enact). Eles são objetos distintos e ao mesmo tempo relacionados. São múltiplas formas da realidade” (MOL, 1999, p. 77). Desse ponto de vista, conforme enfatizam Moraes e Arendt (2013, p. 315), não se trata mais de acompanhar a estabilização de objetos em redes, mas de "lidar com um processo mais precário, contínuo, fluido, aberto, um modo nunca acabado de fazer existirem realidades". No caso mais específico do HIV, essas produções, implicaçóes e engajamentos 
continuam a ocorrer em diferentes momentos. Como será visto mais adiante, há também desdobramentos e implicaçóes em relação à carga viral indetectável: uma nova condição ou posicionamento (bio)identitário que mobiliza atores, práticas, performances, tecnologias, números, tensões, disputas, discursos, valores etc.

Utilizamos, assim, essas ideias de $\operatorname{Mol}(1999 ; 2008)$ não apenas porque podemos, hoje, falar da Aids como uma doença crônica, e seu cuidado devendo ocorrer de forma contínua, decorrente de novos medicamentos, efeitos [colaterais] e rotinas terapêuticas, mas também porque buscamos destacar as "práticas" do viver com HIV/ Aids; e desta forma, reconhecer as tensôes contínuas, desdobramentos e a polifonia de histórias e participaçôes (coletivas) no cuidado (e tratamento) que passam a existir no cotidiano de pessoas vivendo com HIV/Aids (PVHA), com e apesar dos avanços da terapia antirretroviral. No caso mais específico deste artigo, como tais práticas são performadas nos consultórios médicos, como os/as profissionais lidam com os avanços biotecnológicos e negociam com as PVHA o cuidado em torno da carga viral indetectável e a não transmissibilidade do HIV.

Certamente, para além de pensar o HIV/Aids "apenas" como outra doença crônica, devemos localizá-lo em suas especificidades, ou seja, vinculado ainda a sexualidades tidas como "promíscuas" (SQUIRE, 2010) e a corpos vistos como "perigosos" (CUNHA, 2012). É oportuno, portanto, considerar o lugar que PVHA continuam a ocupar, muitas vezes vistas como cidadãs de "segunda categoria" (SIMÓES, 2018, p. 333). Se há outras possibilidades e "posicionamentos" produzidos com o uso de terapias antirretrovirais, que permitiram, inclusive, falar de pessoas vivendo com HIV/Aids, há imagens e valores (morais) que continuam a persistir nesse cenário de avanços biotecnológicos.

\section{Considerações metodológicas}

Conforme já sinalizado, este artigo é produto de uma trajetória de pesquisa sobre sociabilidades de jovens vivendo com HIV/Aids, com ênfase nos novos discursos/ práticas biomédicos e seu impacto nas relaçôes afetivo-sexuais desses/as jovens. Desde 2012, uma série de informaçóes e relatos tem sido gerada/armazenada, a partir de conversas informais, observação participante e entrevistas semiestruturadas e abertas (on-line e off-line) com pessoas/jovens vivendo com HIV/Aids e profissionais de saúde. Destaca-se, também, o acompanhamento longitudinal de um grupo no 
Facebook criado por/para pessoas (con)vivendo com HIV/Aids, um espaço de acolhimento, informação e troca de experiências sobre o viver com HIV (SILVA; DUARTE; ALVES, 2017). Neste artigo, discutimos especificamente as narrativas de quatro médicos/as infectologistas entrevistados/as em seus respectivos consultórios de um Serviço de Assistência Especializada (SAE) em Salvador/Bahia.

Durante os meses de março a novembro de 2017, houve a interação com jovens vivendo com HIV/Aids, com idade entre 18 e 30 anos, principalmente $\mathrm{HSH}$, e médicos/as infectologistas do SAE onde a pesquisa foi desenvolvida. Buscamos criar um espaço dialógico e conversacional, com o objetivo de produzir narrativas sobre os avanços no cenário do HIV/Aids, e mais precisamente sobre a carga viral indetectável ${ }^{2}$. Adotando uma abordagem narrativa, as entrevistas abertas com os/as profissionais foram orientandas por uma pergunta geral (e disparadora) sobre a rotina das consultas e como aconteciam as conversas sobre carga viral indetectável com seus/ suas pacientes. As entrevistas foram realizadas por um estudante de pós-graduação e pelo coordenador do projeto. $\mathrm{Na}$ análise, foi desenvolvida a leitura exploratória das narrativas em foco, buscando identificar temas, questôes e atores presentes e que se deslocavam nos relatos/histórias em torno da condição de indetectável.

Destacamos que as narrativas, ainda que sejam produzidas e situadas em histórias particulares, dialogam e se interconectam entre si, na medida em que "atualizam" ou trazem outras "vozes" (BAKHTIN, 2003) de nossa história e cultura. Nesse sentido, entendemos as narrativas a partir de uma abordagem socioculturalmente orientada, ou seja, seguindo o pressuposto de que narrativas "pessoais" e "culturais" estão interconectadas (SQUIRE, 2013). Partimos, assim, de uma perspectiva dialógica e performativa para a construção e análise das narrativas, que pode envolver muitas "mídias" e "meios linguísticos", produzindo significados através do movimento, progressão e sequenciamento de signos (SQUIRE, 2013). Como desenvolvem Squire et al. (2014), este movimento pode ser interrompido, contraditório e não linear.

Cabe destacar que utilizamos também uma abordagem mais "pragmática" (SQUIRE et al., 2014) para discutir e compreender estes relatos, mediados pela existência das novas tecnologias de comunicação e biomédicas, que vêm possibilitando a produção de novas narrativas auto/biográficas e sobre o HIV/Aids. Ressaltamos, portanto, que essas novas narrativas, ou versóes do HIV/Aids, como resultados situados ou contingentes, são produto de atividades coletivas de muitos atores - humanos e não humanos (RACE, 2012). 
A pesquisa foi aprovada pelo comitê de ética do ISC/UFBA - número do parecer 1.684.862. Todas as entrevistas foram realizadas e gravadas após elucidação dos objetivos da pesquisa e assinatura do termo de consentimento livre e esclarecido. Todos/as os/as interlocutores/as foram informados/as de que o anonimato das informações fornecidas estaria garantido em todas as formas de divulgação dos resultados da pesquisa.

\section{Resultados e Discussóes}

Neste artigo, a ênfase nas narrativas de médicos/as sobre a carga vital indetectável e não transmissibilidade do HIV está motivada pelos questionamentos de PVHA e pela carência de estudos que explorem como os avanços biomédicos em HIV performam suas orientaçôes de cuidado, principalmente em relação à carga viral indetectável. Nessa direção, como ponto de partida, gostaríamos de trazer uma resposta muito emblemática de uma PVHA - produzida em dezembro de 2016, em um fórum de discussão em uma página do Facebook para pessoas (con)vivendo com HIV/Aids - à questão sobre "transar ou não com preservativo, sabendo que o parceiro soropositivo está com o tratamento em dia e com carga viral indetectável”:

Já tive parceiros que optaram por não usar a camisinha. Eram negativos e continuaram negativos! Se você faz seu tratamento de forma regular e correta, e sua carga viral está indetectável, não precisa se preocupar! Eu poderia dizer pra você consultar seu médico, mas como nem todos os médicos se sentem confortáveis em conversar sobre o assunto, infelizmente pode ser que você saia da [consulta] com tantas dúvidas quanto entrou, rs (Fórum de discussão no Facebook - dezembro/2016).

Essa resposta mostra os dilemas e controvérsias que persistem ou são atualizados no cenário do HIV/Aids, apesar de avanços biomédicos importantes, capazes de frear a circulação/transmissão do vírus. ${ }^{3}$ Gostaríamos, assim, de chamar atenção para dois aspectos que apareceram nas conversas com médicos/as infectologistas: as mudanças possíveis que podem ocorrer com a carga viral entre um momento e outro, pós-exame ou pós-resultado de carga viral indetectável, como também as dificuldades que os/as profissionais/infectologistas têm para falar com seus/suas pacientes sobre a não transmissibilidade do HIV com a carga viral indetectável.

Como enfatiza Dr. Drum, o objetivo do tratamento é alcançar a carga viral indetectável. No entanto, existem questôes práticas para as quais ele chama atenção, que, de certa forma, mostram a cautela de alguns médicos/as de se falar abertamente 
sobre a não transmissibilidade do HIV quando se está com a carga viral indetectável. Ou, em suas palavras: "evito falar que, se ele tiver carga viral indetectável, não vai transmitir, mas eu explico a ele que, com carga viral indetectável, ele diminui a chance de transmissão". Segundo este infectologista, como também será ressaltado por outros/as, ainda que faça referências a estudos com casais sorodiscordantes, por exemplo, em que "pacientes que estavam indetectáveis e sem utilizar a camisinha, e sem utilizar métodos como PEP”, ${ }_{4}^{4}$ não transmitiram o HIV para seu/sua parceiro/a, há uma diferença entre o momento do exame e o que pode acontecer depois. Uma mudança temporal que, a depender de outros atores e contingências, pode tornar a carga viral novamente detectável:

[...] Tem duas coisas importantes pra você, pra gente entender, né. Uma coisa é a pessoa tá
indetectável no momento em que ela faz o exame. Não quer dizer que hoje ela não toma o
remédio e amanhã ela tá indetectável. Ou, hoje ela tomou algum remédio, tipo, o Ome-
prazol, que não pode ser tomado com Atazanavir, por exemplo, porque vai interagir com
remédio. Ela tá tomando o remédio, mas por outro remédio que ela tomou e que interagiu
diminuiu a essência do remédio, e ela vai ter uma carga detectável amanhã. Então, essa
carga, esse status de vírus pode infectar um parceiro. (Dr. Drum, infectologista)

As ressalvas apontadas na discussão sobre carga viral indetectável e (não) uso do preservativo são sustentadas também pela possibilidade de outras infecçóes sexualmente transmissíveis, na medida em que continuam a acontecer e, portanto, devem justificar o uso da camisinha "em todos os momentos do sexo". Além da necessidade de uso da camisinha ("sempre”), independentemente da carga viral (detectável ou indetectável), Dr. Drum coloca ainda em destaque a diferença entre carga viral indetectável na amostra de sangue e existência do vírus no organismo. Para ele, independentemente da quantidade que se utilize como parâmetro ou do limite de detecção (menor de 40 cópias, por exemplo), "existe vírus no corpo", ou seja, "naquela amostra não encontrou, mas existe vírus no corpo, no lugar chamado santuários, nos linfonodos, no intestino etc. Mas de indetectável pra 40 é uma coisa mínima, concorda?" É este mínimo que parece fazer alguma diferença ou tornar a discussão sobre não transmissão do HIV quando se é indetectável um tema difícil ou delicado durante as consultas médicas.

Por sua vez, Dra. Venus chama a atenção para esta diferença entre limite de detecção e existência de vírus no corpo. Partindo da mesma premissa, enfatiza que, mesmo com o resultado de indetectável, existe alguma quantidade de vírus, ou 
seja: "se o limite de detecção está abaixo de 20 cópias, podem existir 17 cópias por mililitro, 15 cópias, 7 cópias, 2 cópias”. Conforme esclarece, há exames que podem aumentar ou diminuir este limite. Entretanto, apesar de se sentir mais tranquila, principalmente diante de "pacientes mais relaxados, que evitam, que não querem usar preservativo", ou mesmo diante de um casal que quer ter filho, não se sente segura em dizer que o "risco é zero":

O que acontece, o que é a carga viral indetectável, é quando o limite mínimo de detecção do exame...Existem exames que conseguem detectar, por milímetro cúbico de sangue, até 40 cópias de vírus e tem exames que são melhores e conseguem detectar até 20 cópias. Entẫo, quando tá abaixo desse limite de detecção, por milímetro cúbico de sangue, o paciente está indetectável, entendeu? Significa que no sangue daquele paciente, por milímetro cúbico, tem menos de 20 cópias de vírus, entendeu? Isso dá segurança de dizer que tem pouco vírus demais, né, circulante no sangue. Então, hoje em dia, a gente sabe que tem estudos inclusive que mostram que o paciente indetectável não transmite. Eu, particularmente, não me sinto segura de virar pra um paciente e falar: "você está indetectável e você não transmite". A carga viral indetectável está abaixo de 20 cópias, ela não está abaixo de zero. Se existe vírus circulante, eu sempre digo que o risco é mínimo. Existem colegas que se sentem seguros de dizer que o risco é zero. Eu não me sinto assim. Eu explico que o risco é mínimo, entendeu? (Dra Venus, infectologista).

Por sua vez, considerando o "gap" entre uma consulta e outra (exame de carga viral de 6 em 6 meses), Dr. Drum faz a seguinte pergunta: "Será que essa pessoa está indetectável durante todo o período?” É necessário, portanto, destacar que a dúvida parece se sustentar na ideia de desempenho de cada indivíduo em relação ao tratamento do HIV/Aids. Ideia que parece, também, colocar em pauta as habilidades, atributos e características de cada sujeito no processo do cuidado consigo e com o outro. De certa forma, a dúvida se desloca dos "dados/evidências" para o sujeito. De acordo com alguns desses/as médicos/as, se é possível, por um lado, concordar com a premissa de que "indetectável = intransmissível”, por outro, é preciso ter cautela devido às dificuldades de cada "pessoa" no processo de cuidado com o HIV. Ou seja, "é capaz de a pessoa até em uma semana parar de tomar o remédio, pode transar com alguém sem camisinha, transmitir a doença”.

Tá muito claro que a pessoa que é indetectável não transmite, mas isso é muito mais complexo do que a gente imagina. A pessoa não está detectável naquele dia que ela fez o exame. Um dia, dois dias, um mês depois, ela pode estar detectável. Ou seja, vamos fazer o exame e você tá indetectável, tá bom, vai ter uma relação hoje, amanhã eu não sei. É isso que eu tô querendo dizer, eles estão utilizando um modelo matemático pra uma coisa que não é matemática. (Dr. Drum, infectologista). 
Essa insegurança também se justifica mediante a dúvida sobre a vida do outro, ou melhor, quem é o outro, principalmente quando os jovens são vistos como propensos ao "risco" (CUNHA, 2012). Dr. Drum chama atenção para o modo como os jovens estâo "expostos", "aparentemente" sem se preocupar com o risco. Daí a importância de ter cuidado com o tipo de informação que se veicula, ou seja, se essa informação [sobre carga viral indetectável] for "usada da maneira errada, vai deixar eles menos ainda preocupados". Neste sentido, para ele, é preciso sustentar que existe uma chance (mesmo mínima) de transmissão do vírus, não apenas devido às circunstâncias pós-exame, mas também considerando as práticas sexuais desprotegidas, e mesmo a quantidade do HIV no sangue. Nesta direção, em qualquer situação, sem camisinha, existe uma probabilidade de infecção/transmissão, o que não significa "certeza" em acontecer. Desse ponto de vista, a segurança possível seria o uso da camisinha em todas as práticas sexuais:

\begin{abstract}
Não existe uma equação pra isso, mas se o cara estiver indetectável, diminui a chance [de transmissão], porém, ele tava indetectável há três meses atrás, hoje ele tá ali, não tomou remédio, bebeu ontem, vomitou, tá detectável. Associado a isso, se ele fizer sexo anal, aumenta a chance [de infectar]. Se a pessoa estiver menstruada, aumenta a chance [de infectar]. Se a carga viral for de - da pessoa que tá tomando [medicaçâo antirretroviral] - se ela estiver indetectável, pode, mas se não tiver, se tiver com 100 cópias é uma coisa, se tiver com 20 cópias é outra, se tiver com um milhão de cópias é outra coisa. Quer dizer que vai transmitir? Não. Quer dizer que não vai transmitir? Também não. E qual é a segurança? Nenhuma. Só tem uma segurança, a da camisinha. Ninguém quer saber, a chance é baixa, a chance é alta? Ninguém me pergunta: “é alta, é baixa?”. A pessoa quer saber: "existe a chance?", "existe", ponto. Nâo é? Existe, use camisinha, porque existe a chance. Então é um assunto tâo complicado que as pessoas ainda não falam muito abertamente sobre isso. Você pode aí, é, divagar, filosofar, mas é o clichê: tem que usar camisinha. (Dr. Drum, infectologista).
\end{abstract}

Na mesma direção, Dr. Actus enfatiza que nunca se deve "quebrar a barreira do preservativo". Para sustentar seu argumento, diz que não se pode "confiar no parceiro", ou, complementa, por que pode haver "uma quebra de protocolo do outro”. São as possíveis “falhas” (por exemplo, no uso de medicamento) que, mesmo entre parceiros soroconcordantes, o fazem frisar a necessidade de uso da camisinha "sempre", até mesmo pela possibilidade de reinfecção: ${ }^{6}$

A minha opiniâo é nunca quebrar a barreira do preservativo. [...] Mesmo indetectável, mesmo usando profilaxia pré-exposição. É a minha opinião. Eu não posso confiar no parceiro. Eu posso ter um parceiro que foi desleixado, que não tá tomando remédio, ele não ficou mais indetectável e ele tá detectável, ele pode me contaminar e a pessoa vai ficar contaminada cronicamente. [...] o estado de detectabilidade ele vai existir no momento 
em que ele começar a falhar. Aí ele pode falhar um mês, aí volta, aí volta pra indetectável, aí depois começam a aparecer cópias, que é a carga viral que eu acompanho que vai me dizendo. Então, eu já posso estar trazendo mutaçóes nesse vírus, ele já pode estar começando a ficar resistente, né. Até entre os parceiros que são os dois soropositivos a gente não orienta porque pode ter esse que tá falhando passar a mutação pra o outro e destruir o tratamento do outro. E pra aquele que não tem, que está imaginando que o parceiro tá tomando a medicação, ele receber uma detectabilidade de carga e a possibilidade de transmissão e ele vir a ser contaminado. Então, assim, eu não oriento a nenhum paciente meu quebrar protocolo de prática de sexo seguro, como o uso do preservativo, nem que esteja indetectável. (Dr. Actus, infectologista).

Essa insegurança em relação ao outro (indetectável) faz também com que, em caso de acidente ou falha no uso do preservativo entre casais sorodiscordantes, em que o/a parceiro/a encontra-se indetectável, Dr. Drum prescreva a profilaxia pósexposição (PEP):

Inclusive, eu trabalho no M.C., se chega uma paciente e diz que tá indetectável e tal, eu passo o remédio. Casal sorodiscordante, não necessariamente homem e mulher, pode ser duas mulheres, ou dois homens, se o casal chega, são sorodiscordantes: "olhe, nós temos uma relação, eu tenho HIV e a outra pessoa, não", um tem HIV e o outro não tem, teve uma relação desprotegida, o parceiro está indetectável, o risco é baixíssimo, porém eu me sinto à vontade mais em passar a profilaxia, a PEP. (Dr. Drum, infectologista).

Dra Cam destaca que não há "100\% de certeza" de que não haverá transmissão do HIV com a carga viral indetectável. Em seu argumento, fala sobre "viremia transitória" e, como outros/as infectologistas que participaram da pesquisa, que a carga viral é um "momento", é um exame que se faz de seis em seis meses, com o resultado podendo ser alterado ao longo do tempo, fazendo com que o vírus volte a circular, tornando a pessoa HIV positivo um "potencial transmissor novamente". Por isso, permanece a "indicaçấo do uso do preservativo", inclusive porque "existe uma série de outras doenças sexualmente transmissíveis que muitas vezes o paciente não tem e ele pode contrair".

Em relação ao que a gente tem orientado, normalmente, eu explico que o risco de transmissão do HIV é muito baixo se ele estiver com carga viral indetectável, embora a gente não tenha como assegurar que é nulo. Os pacientes com HIV, eles podem fazer episódios de viremia transitória, que a gente chama de blip. Então, por exemplo, depois de uma vacinação, depois de uma infecção, ele pode ter uma ativação imune que vai fazer com que o vírus circule um pouquinho e a gente não tem como garantir que no momento de uma relação desprotegida, com essa viremia transitória, ele não vai ser capaz de transmitir o vírus. Então, o que eu oriento é que o paciente mantenha relação sexual com preservativo, pensando em proteger o parceiro, mas, sobretudo, na sua própria proteção em relação às outras doenças sexualmente transmissíveis. (Dra Cam, infectologista). 
Em relação às mudanças possíveis da carga viral, Dra Venus traz o exemplo de um paciente que não conseguia "zerar" a carga viral por não ter regularidade no horário do medicamento. Fala também sobre a possibilidade de mudanças de status (indetectável-detectável-indetectável) no mesmo período de seis meses. Mudanças que, para ela, "relativizam" a informação sobre não transmissibilidade do HIV com carga viral indetectável:

Eu tive um paciente hoje, que ele veio pra mim, e ele disse que toma todos os dias, mas ele não tem regularidade de horário. A penúltima carga viral que ele fez, ele tava com 44 cópias e a última que ele fez agora ele está com 56 cópias. É uma carga viral baixa, mas ele não conseguiu zerar por conta disso aí, porque sempre fica nesse - como é que eu vou dizer - nessa falhazinha de horário, né. "Um dia eu tomo às 10 horas, no outro dia eu tomo às 2 horas da manhâ”, porque tá, pelo menos pra ele, diretamente relacionado com o horário que ele vai dormir. A gente tenta conversar pra convencer a manter um horário fixo, mas nem sempre é possível. Então, se pode existir? Pode. A gente sabe que, tipo assim, o paciente que faz carga viral de 6 em 6 meses e nesse último mês todo ele tomou, ele vai fazer carga viral hoje, ele vai estar indetectável. Se ele ficar sem tomar cinco meses e no último mês, antes dele vir pra mim, ele voltar a tomar regularmente, é possível ele estar indetectável de novo, entendeu? Entáo é muito relativo [...] (Dra Venus, infectologista).

Finalmente, conforme lembram alguns dos/as infectologistas, há jovens que chegam no consultório com muita informação técnica sobre HIV/Aids, muitas dessas disponíveis e acessadas através da internet. São conhecimentos atuais e relevantes que ajudam a diminuir o sofrimento pós-diagnóstico, principalmente quando passam a compartilhar estas informaçôes, e mais precisamente, conforme tem mostrado um desses estudos (PARTNER 1), de que não há casos de transmissão do vírus em casais sorodiscordantes quando o parceiro encontra-se em tratamento e com carga viral indetectável (RODGER et al., 2016).

Nos consultórios, as conversas (e linguagem) sobre carga viral indetectável são sustentadas no modo como os/as médicos/as percebem seus/uas pacientes, considerando seu nível sócio-educacional. Ou seja, parecem considerar um tipo de expertise ou conhecimento acumulado que torna alguns/as pacientes mais propícios à discussão aberta sobre a não transmissibilidade do HIV com carga viral indetectável do que outros/as. Conforme esclarece $\mathrm{Dr}^{\mathrm{a}} \mathrm{Cam}$, é preciso "adequar a conversa à compreensão do paciente". Nestes termos, o que parece estar em cena é o medo ou receio de que o/a paciente "relaxe" no cuidado/tratamento e proteçáo (uso do preservativo) consigo e com o outro. Portanto, está em cena um modo de agir (e 
se comunicar) a partir de uma "antecipação" (e atribuição de valor) sobre quem é o outro (capaz ou incapaz), o/a qual pode modificar o "rumo" da prevençáo.

Se eu tiver um paciente que seja altamente culto, altamente é, um médico ou entâo alguém que seja um engenheiro, um arquiteto, um psicólogo, né, alguém que tenha um QI que vai entender as coisas, a gente pode passar pra ele, ele tem o direito de saber das coisas, ele tem o direito de decidir. Existem situaçóes que, sim, eu vou passar isso pro paciente: "olhe, se você tomar o remédio, você fica indetectável, sim, se tomar direitinho". Isso pode ser passado pro paciente, eu não vejo problema nisso. Com certeza eu já falei isso pra algum paciente. Mas eu dou a ele as ferramentas pra ele entender que indetectável é momentâneo, pode ser sustentado se ele se garantir. (Dr. Drum, infectologista).

Como destaca Lupton (1999, p. 148), correr riscos desnecessários é visto como algo "imprudente", "irresponsável" e ainda "desviante", uma evidência de "falta de habilidade para regular o self”. Esses dilemas em relação ao indetectável parecem, portanto, atualizar uma discussão sobre as fronteiras entre ordem e desordem social (DOUGLAS, 1991), ou mais especificamente colocar em pauta uma produção (coletiva) que separa, normatiza, hierarquiza ou pôe nos devidos lugares "positivos/as" e "negativos/as", na medida em que os/as soropositivos/as podem contaminar/infectar os/as soronegativos/as, ou mesmo em que alguns/algumas são tidos/as como mais excessivos/as, descontrolados/as ou instáveis do que outros/as. Por outro lado, a condição de indetectável também pode borrar estas fronteiras, misturando posiçóes e pessoas, ou seja, "confundindo" positivos/as e negativos/ as. Esta pode ser, também, uma atividade "arriscada", pois coloca em xeque as fronteiras conceituais já aceitas e estabelecidas (LUPTON, 1999). É interessante lembrar que a possibilidade de atravessar limites (culturais, sócio-históricos e materialmente reconhecidos) mobiliza diferentes sentimentos/emoçóes, entre eles, medo, ansiedade, preocupação e culpa (SILVA, 2009).

\section{Consideraçóes finais}

Os dilemas em torno da carga viral indetectável, como um assunto delicado (e controverso) nos consultórios médicos, a despeito de estudos científicos significativos, sugerem atualizaçóes da imagem do risco/perigo historicamente associada à Aids. Ou melhor, parecem falar de sujeitos potencialmente perigosos, que podem reincidir em práticas sexuais desprotegidas ou relaxar no cuidado consigo e com o outro. Para além das "falhas" e instabilidades no tratamento e respostas do próprio corpo, o que continua em pauta são as fraquezas ou falhas morais associadas às pessoas 
vivendo com HIV/Aids, e mais especificamente àquelas sexualidades tidas como desenfreadas ou promíscuas.

Não queremos dizer que o uso do preservativo não seja mais importante ou necessário, inclusive como forma de proteção contra outras IST. O que estamos a enfatizar é que existem (e existirão) contingências e situaçóes da vida concreta que podem tornar a camisinha algo secundário, falho ou mesmo dispensável, considerando a fluidez dos prazeres, desejos e negociaçôes que ocorrem em contextos relacionais diversos (incluindo relacionamentos entre parceiros/as com sorologia diferente). Nesse sentido, diante das vicissitudes da vida, é imprescindível que se reconheça e se discuta abertamente outras formas/métodos de prevenção viáveis e já possíveis, para além do uso da camisinha, como é o caso das novas tecnologias biomédicas de prevenção, por exemplo, PrEP 7 , PEP, Testar e Tratar (Tratamento como prevenção $-\mathrm{TcP}^{8}$ ), além daqueles métodos de gerenciamento do risco que ocorrem na vida concreta, considerando as próprias experiências, práticas e desejos sexuais. Portanto, não se trata "apenas" de reprodução de métodos/técnicas, as PVHA participam "ativamente" do processo de prevenção/cuidado. Elas interagem entre si, compartilham experiências e informaçôes, tomam decisóes mediadas por seus recursos, desejos, saberes disponíveis e atores em cena; enfim, pelo que é "possível" fazer em momentos específicos. Um processo que se apresenta de forma aberta, com possibilidades de experimentação e mudanças de curso.

Há, portanto, uma diversificação (e complexificação) de métodos que, conforme aponta Terto Jr. (2015, p. 160), para sua maior efetividade, "deveriam ser usados em combinação, segundo as necessidades e circunstâncias de indivíduos e populações”. Isso implica também desenvolver outras estratégias de redução de vulnerabilidades de indivíduos/grupos. Estratégias estas que possam combater o estigma e a discriminação que constroem determinadas vidas como "vidas que não importam" (SEFFNER; PARKER, 2016, p. 298), bem como combater práticas/discursos que fazem "pesar" ou "valer" diferentemente estes corpos (BUTLER, 2008), como é o caso dos corpos com HIV/Aids. E dessa forma, desenvolver estratégias e políticas que possam ir além de uma perspectiva de prevenção focada na gestão "solitária" dos riscos (SIMÓES, 2018), a partir do manejo de testes e tratamentos.

Finalmente, a discussão e o reconhecimento público de que "indetectável = intransmissível” (CONSENSUS STATEMENT, 2018) não apenas podem diminuir o estigma em relação ao HIV/Aids, mas também podem impactar positivamente a 
vida de muitas pessoas, diminuindo o sofrimento e sentimentos de medo (e culpa) pela possível transmissáo do vírus. Isto significa um posicionamento ético em direção ao outro, pelo reconhecimento de seu lugar no mundo (BAKHTIN, 2003, p. 21); portanto sem reduzi-lo a um/a "portador/a" ou "potencial" transmissor/a de um vírus. Além de assegurar um direito à informação, conforme normatizado no protocolo de manejo clínico (BRASIL, 2018; p. 90), como "direito da pessoa vivendo com HIV e das pessoas não reagentes para o HIV saberem: 1) que nunca foi comprovada uma transmissão por pessoa com HIV em supressão viral; 2) que o risco estimado nesses casos é tão pequeno que pode ser considerado insignificante".

Destaca-se que esses novos dados de pesquisa/informação sobre a carga viral indetectável não excluem as discussôes sobre adesão ao tratamento, bem como sobre os obstáculos/barreiras que podem dificultar tanto o diagnóstico quanto o tratamento para HIV/Aids. Nesse sentido, é fundamental reconhecer que toda a cascata de cuidado em HIV é resultante da interação de múltiplos atores e que as associações ou interações de elementos/atores diversos podem mudar os "rumos" ou possibilidades/ itinerários do cuidado (SILVA; SANTOS; DOURADO, 2015). Nesse sentido, para além das "falhas" individuais, será crucial que possamos situar as condiçóes concretas em que ocorrem este cuidado, como também dar destaque às práticas em que se deslocam (e interagem) esses atores, para que vidas ou existências possíveis sejam viabilizadas. Para além da busca de "controle", uma prática (do cuidado) que ponha em cena outras necessidades, como ser resistente/"tenaz", "adaptável” e "perseverante" diante de uma situação (crônica) específica (MOL, 2008). ${ }^{9}$

\section{Agradecimentos}

À Capes, pela concessão de bolsa de pós-doutorado ao primeiro autor do artigo (Estágio Sênior no Exterior - 88881.120900/2016-01), e à professora Corinne Squire, pelas discussóes sobre narrativa e HIV/Aids desenvolvidas pelo respectivo autor no Center of Narrative Research, University of East London. Ao CNPq e FAPESB, pelo apoio dado aos projetos de pesquisa sobre sociabilidades de jovens vivendo com HIV. Aos profissionais e jovens do SAE onde a pesquisa foi realizada, pela abertura e disponibilidade para contribuir com tópicos e questôes tấo delicadas de seu cotidiano. À doutoranda Renata Lúcia e Silva e Oliveira, pela colaboração na realização de entrevistas com jovens. 


\section{Referências}

BAKHTIN, M. Estética da criação verbal. São Paulo: Martins Fontes, 2003.

BAUMAN, Z. O mal-estar da pós-modernidade. Rio de Janeiro: Jorge Zahar, 1998.

BECK, U. From industrial society to the risk society: questions of survival, social structure and ecological enlightenment. Theory, Culture \& Society, v. 9, p. 97-123, 1992.

BRASIL. Ministério da Saúde. Boletim Epidemiológico Aids/DST. Ministério da Saúde. Secretaria de Vigilância em Saúde - Departamento de Vigilância, Prevenção, e Controle das Infecçôes Sexualmente Transmissíveis, do HIV/Aids e das Hepatites Virais.Brasilia, 2017.

. Ministério da Saúde. Protocolo Clínico e Diretrizes Terapêuticas para Manejo da Infecção pelo HIV em Adultos. Ministério da Saúde. Secretaria de Vigilância em Saúde - Departamento de Vigilância, Prevenção, e Controle das Infecções Sexualmente Transmissíveis, do HIV/Aids e das Hepatites Virais. Brasília, 2018.

BUTLER, J. Cuerpos que importan: sobre los límites materiales y discursivos del "sexo". 2a Edição. Buenos Aires: Paidós, 2008.

CASTIEL, L. D. Dédalo e os dédalos: identidade cultural, subjetividade e os riscos à saúde. In: Czeresnia, D.; Freitas, C.M. (Orgs.). Promoção da saúde: conceitos, reflexôes, tendências. Rio de Janeiro: Fiocruz, 2003, p. 79-95.

COHEN M.S. et al. Antiretroviral Therapy for the Prevention of HIV-1 Transmission. N Engl JMed., v. 375, n. 9, p. 830-9, 2016.

CONSENSUS STATEMENT. Risk of sexual transmission of HIV from a person living with HIV who has an undetectable viral load, 2016/2018. Disponível em: <https://www.preventionaccess. org/consensus>. Acesso em: 7 dez. 2018.

CUNHA, C. Os muitos reveses de uma "sexualidade soropositiva": o caso dos jovens vivendo com HIV/Aids. Sexualidad, Saludy Sociedad, v. 10, p. 70-99, 2012.

DAVIS, M. Antiretroviral treatment and HIV prevention: perspectives from qualitative research with gay men with HIV in the UK. In: Davis, M.; Squire, C. HIV treatment and prevention technologies in international perspective. UK: Palgrave Macmillan, 2010, p. 126-143.

. Identity, Expertise and HIV Risk in a Case Study of Reflexivity and Medical Technologies. Sociology, v. 41, n. 6, p. 1003-1019, 2007.

DAVIS, M.; FRANKIS, J.; FLOWERS, P.Uncertainty and 'technological horizon' in qualitative interviews about HIV treatment. Health, v. 10, n. 3, p. 323-344, 2006.

DAVIS, M.; SQUIRE, C. HIV technologies. In: Davis, M.; Squire, C. HIV treatment and prevention technologies in international perspective. UK: Palgrave Macmillan, 2010, p. 1-17. 
DE COCK, K M; JOHNSON, A M. From exceptionalism to normalisation: a reappraisal of attitudes and practice around HIV testing. BMJ, v. 316, p. 290-293, 1998.

DOUGLAS, M. Pureza e perigo: ensaios sobre as noções de poluição e tabu. Lisboa: Edições 70, 1991.

GIDDENS, A. A vida em uma sociedade pós-tradicional. In: BECK, U.; GIDDENS, A.; LASH, S. Modernização reflexiva: política, tradição e estética na ordem social moderna. São Paulo: Editora da Universidade Estadual Paulista, 1997, p. 73-133.

FLOWERS, P. HIV transitions: consequences for self in an era of medicalization. In: DAVIS, M.; SQUIRE, C. HIV treatment and prevention technologies in international perspective. UK: Palgrave Macmillan, 2010, p. 109-125.

FOUCAULT, M. História da sexualidade 1: a vontade de saber. Rio de Janeiro: Graal, 2001.

GRUPO DE INCENTIVO À VIDA. I=I. Boletim Vacinas, n. 32, p. 2-8, 2019.

GRULICH, A. et al. HIV transmission in male serodiscordant couples in Australia, Thailand and Brazil. 2015 Conference on Retroviruses and Opportunistic Infections (CROI), Seattle, USA, 2015.

GUIMARAES, M. D. C. et al. Comparing HIV risk-related behaviors between 2 RDS national samples of MSM in Brazil, 2009 and 2016. Medicine (United States), v. 97, n. 1S, p. S62-S68, 2018.

JEFFRIES IV, W. et al. HIV stigma experienced by young men who have sex with men (MSM) living with HIV infection. AIDS Education and Prevention, v. 27, n. 1, p. 58-71, 2015.

LUPTON, D. Risk. London and New York: Routledge, 1999.

MAKSUD, I; FERNANDES, N. M; FILGUEIRAS, S. L. Tecnologias de prevenção do HIV e desafios para os serviços de saúde. Rev. Bras. Epidemiol., v. 18, supl. 1, p. 104-119, 2015.

MOL, A. Ontological politics. A word and some questions. In: LAW, J.; HASSARD, J. (Eds). Actor network theory and after. Oxford, UK: Blackwell, 1999, p. 74-89.

The logic of care: health and the problem of patient choice. London \& New York: Routledge, 2008.

MORAES, M. O.; ARENDT, R. J. J. Contribuiçóes das investigaçóes de Annemarie Mol para a psicologia social. Psicologia em Estudo, Maringá, v. 18, n. 2, p. 313-321, 2013.

ORTEGA, F.; ZORZANELLI, R. Corpo em evidência: a ciência e a redefinição do humano. Rio de Janeiro: Civilização Brasileira, 2010.

RACE, K. Framing Responsibility HIV, Biomedical Prevention, and the Performativity of the Law. Bioethical Inquiry, v. 9, p. 327-338, 2012. 
RODGER, A. J. et al. Risk of HIV transmission through condomless sex in serodifferent gay couples with the HIV-positive partner taking suppressive antiretroviral therapy (PARTNER): final results of a multicentre, prospective, observational study. Lancet, v. 393, p. 2428-38, 2019.

Sexual activity without condoms and risk of HIV transmission in serodifferent couples when the HIV-positive partner is using suppressive antiretroviral therapy. JAMA,316, p.171-181, 2016.

ROSENGARTEN, M. et al. After the euphoria: HIV medical technologies from the perspective of their prescribers. Sociology of Health \& Illness, v. 26, n. 5, p. 575-596, 2004.

SEFFNER, F.; PARKER, R. Desperdício da experiência e precarização da vida: momento político contemporâneo da resposta brasileira à aids. Interface (Botucatu), v. 20, n. 57, p. 293-304, 2016.

SILVA, L. A. V. Masculinidades transgressivas em práticas de barebacking. Rev. Estud. Fem., v. 17, n. 3, p. 675-699, 2009.

SILVA, L. A. V.; DUARTE, F. M; ALVES, G. R. Sociabilidades “positivas” em rede: narrativas de jovens em torno do HIV/aids e suas tensões cotidianas. Physis, v. 27, n. 2, p. 335-355, 2017.

SILVA, L. A. V.; SANTOS, M.; DOURADO, I. Entre idas e vindas: histórias de homens sobre seus itinerários ao serviço de saúde para diagnóstico e tratamento de HIV/Aids. Physis, v. 25, n. 3, p. 951-973, 2015.

SIMÓES, J. A. Geraçóes, mudanças e continuidades na experiência social da homossexualidade masculina e da epidemia de HIV-Aids. Sexualidad, Salud y Sociedad, n. 29, p. 313-339, 2018.

SPINK, M. J. P. Trópicos do discurso sobre risco: risco-aventura como metáfora na modernidade tardia. Cad. Saúde Pública, v. 17, n .6, p. 1277-1311, 2001.

SQUIRE, C. Being naturalised, being left behind: the HIV citizen in the era of treatment possibility. Critical Public Health, v. 20, n. 4, p. 401-427, 2010.

SQUIRE, C. From experience-centred to culturally-oriented narrative research. In: ANDREWS, M.; SQUIRE, C.; TAMBOUKOU, M. Doing Narrative Research. London: Sage, 2013, p. 47-71.

SQUIRE, C. et al. What is narrative research? London: Bloomsbury, 2014.

TERTO JR., V. Diferentes prevençóes geram diferentes escolhas? Reflexôes para a prevenção de HIV/AIDS em homens que fazem sexo com homens e outras populaçôes vulneráveis. Rev. Bras. Epidemiol., v. 18, supl. 1, p. 156-168, 2015.

THE LANCET HIV. U=U taking off in 2017. Lancet HIV. Editorial, v. 4, n. 11, 2017.

UNAIDS. Undetectable = Untransmittable. UNAIDS Explainer, 2018. Disponível em: $<$ https:// unaids.org.br/wp-content/uploads/2018/07/Indetect\%C3\%A1vel-intransmiss\%C3\%ADvel_ pt2.pdf>. Acesso em: 26 ago. 2019. 


\section{Notas}

${ }^{1}$ A pesquisa é um desdobramento da primeira fase do projeto Sociabilidades de jovens vivendo com HIV/ Aids: repercussóes e efeitos da soroidentidade, desenvolvido entre os anos de 2012 e 2015, com apoio do CNPq. O desdobramento deste projeto, com apoio da FAPESB, foi intitulado Sociabilidades de jovens vivendo com HIVlaids: os novos discursos biomédicos e seu impacto nas relaçôes afetivo-sexuais, iniciado em 2016 (e em andamento), com o objetivo de aprofundar a análise sobre as relaçóes afetivo-sexuais desses jovens e a forma como os discursos/práticas biomédicos, principalmente sobre carga viral indetectável, impactam ou aparecem como mediadores desses relacionamentos.

${ }^{2}$ Conforme será discutido ao longo do artigo, as medicaçôes antirretrovirais são capazes de reduzir a quantidade do vírus HIV para níveis indetectáveis. As PVHA com carga viral indetectável não transmitem o HIV em suas relaçóes sexuais.

${ }^{3}$ Apesar de não ser o escopo deste trabalho, é importante lembrar que esses dilemas (discursos sobre medo/culpa por uma possível transmissão do HIV) apareceram em narrativas de jovens que participaram da pesquisa, ainda que já estivessem na condição de indetectáveis.

${ }^{4}$ A profilaxia pós-exposição (PEP) é uma tecnologia de prevenção que consiste no uso de antirretrovirais (ARV) por 28 dias, com início em até 72 horas em que houve a exposiçấo ao HIV. Sobre esta e outras tecnologias de prevenção, ver Maksud, Fernandes e Filgueiras (2015).

${ }^{5}$ Além dos estudos Partner 1 e Partner 2 (RODGER et al., 2019), este último mais especificamente com casais gays sorodiferentes, é importante destacar a existência de agências (UNAIDS, 2018), campanhas internacionais (CONSENSUS STATEMENT, 2018) e grupos de militância, como o Grupo de Incentivo à Vida (GIV, 2019), ressaltando que indetectável = intransmissivel, ou seja, que o risco de transmissão do HIV por via sexual, com carga viral indetectável, é negligenciável, insignificante ou inexistente.

${ }^{6}$ A reinfecção ocorre quando uma pessoa que vive com HIV adquire uma nova cepa do vírus, que pode vir a ser mais resistente aos medicamentos que compóem o seu esquema de tratamento.

${ }^{7}$ A profilaxia pré-exposição (PrEP) refere-se ao uso oral diário de ARV por pessoas HIV negativas, como forma de prevenção à infecção por HIV.

${ }^{8} \mathrm{O}$ tratamento como prevenção $(\mathrm{TcP})$ consiste na recomendação da terapia antirretroviral precoce, na medida em que os ARV possibilitam a supressão viral e não transmissibilidade do HIV, além de reduzir eventos clínicos relacionados ao HIV.

${ }^{9}$ L. A. V. da Silva coordenou o projeto de pesquisa, participando da pesquisa de campo, análise de dados, escrita do texto e revisão crítica relevante do conteúdo intelectual. F. M. D. participou da pesquisa de campo, escrita do texto e revisão crítica relevante do conteúdo intelectual. M. Lima auxiliou na coordenação do projeto, participando da escrita do texto e revisão crítica relevante do conteúdo intelectual. 


\section{Abstract}

\section{Mathematical model for something that is not mathematical: narratives of infectologists about undetectable viral load and HIV non- transmissibility}

This article is based on an international discussion on HIV non-transmissibility when the HIV-positive person is under treatment and has an undetectable viral load. This is one of the results of research on the sociability of young people living with HIV, with emphasis on new biomedical discourses/practices and their impact on the affective-sexual relationships of young people. From March to November of 2017, the researchers interacted with people living with HIV (PLHIV), aged between 18 and 30 years, and infectologists in a Specialized Service in Salvador-BA, Brazil. Beyond significant changes in relation to HIV due to advances in biotechnology, the study focused on some controversies surrounding the non-transmissibility of the virus from the viewpoint of four infectologists. Open interviews and exploratory reading of the narratives were conducted, identifying themes, issues and actors that moved in the reports on the condition of undetectable. The article argues that undetectable viral load appears as a sensitive/ controversial subject in medical offices, updating the PLHIV's position as potentially dangerous that may engage in unprotected sexual practices or "relax" in mutual care. Such narratives raise fundamental ethical issues in care relations, such as the right to information from the perspective of health as a human right.

Keywords: HIVIAIDS; undetectable viral load; biotechnologies; risk; care practices. 